\title{
ANALISIS PERAMALAN NILAI TUKAR RUPIAH TERHADAP DOLLAR DAN YUAN MENGGUNAKAN FTS-MARKOV CHAIN
}

\section{(FORECASTING ANALYSIS RUPIAH EXCHANGE RATE OF DOLLAR AND YUAN USING FTS-MARKOV CHAIN)}

\section{Safira Yasmin Amalutfia', Moh. Hafiyusholeh ${ }^{2}$}

1Universitas Islam Negeri Sunan Ampel Surabaya, safira.amalutfiayasmin@gmail.com 2Universitas Islam Negeri Sunan Ampel Surabaya, hafiyusholeh@uinsby.ac.id

\begin{tabular}{|c|c|}
\hline Info Artikel & Abstract \\
\hline $\begin{array}{l}\text { Received Jul 28, } 2020 \\
\text { Revised Aug 5, } 2020 \\
\text { Accepted Aug 29, } 2020\end{array}$ & $\begin{array}{l}\text { Rupiah exchange rate depreciated by } 70 \% \text { in } 1998 \text { until an } \\
\text { economic crisis occurred due to decline economic growth } \\
\text { reaching - } 13.1 \% \text {. Exchange rate will very influential in } \\
\text { stability of a country's economy. Therefore, forecast is needed } \\
\text { to find out how the state of exchange rate for next few periods }\end{array}$ \\
\hline Kata Kunci: & $\begin{array}{l}\text { to minimize recurrence of economic crisis. Purpose of this } \\
\text { study is to forecast rupiah exchange rate against dollar and }\end{array}$ \\
\hline $\begin{array}{l}\text { Nilai Tukar, FTS-markov } \\
\text { chain. MAPE, Peramalan }\end{array}$ & $\begin{array}{l}\text { yuan using FTS-markov chain. MAPE result for buying and } \\
\text { selling exchange rate of dollar and yuan are } 0.53 \%, 0.48 \% \text {, } \\
0.42 \%, 0.41 \% \text { respectively which proves that model formed } \\
\text { is in very good forecasting criteria so that forecasting can be } \\
\text { done for the next period. Forecasting using FTS-markov } \\
\text { chain produces predictions for } 24 \text { weeks next. }\end{array}$ \\
\hline
\end{tabular}

\section{Cara merujuk artikel} ini:

Amalutfia, S.Y. \& Moh. Hafiyusholeh. (2020). Analisis Peramalan Nilai Tukar Rupiah terhadap Dollar dan Yuan Menggunakan FTSMarkov Chain. Vygotsky: Jurnal Pendidikan Matematika dan Matematika, 2 (2), pp.102-113. Diunduh dari https://www.xxx.

\begin{abstract}
Abstrak
Nilai tukar rupiah terdepresiasi sebesar 70\% pada tahun 1998 hingga terjadi krisis ekonomi yang disebabkan oleh menurunnya pertumbuhan ekonomi mencapai angka $-13.1 \%$. Nilai tukar akan sangat berpengaruh dalam kestabilan perekonomian suatu negara. Oleh karenanya, diperlukan suatu peramalan untuk mengetahui bagaimana keadaan nilai tukar untuk beberapa periode kedepan untuk meminimalisir terjadinya krisis ekonomi terulang kembali. Tujuan dari penelitian ini adalah melakukan peramalan nilai tukar rupiah terhadap dollar dan yuan menggunakan FTS- markov chain. Hasil MAPE untuk kurs jual beli dollar dan yuan masing-masing adalah $0.53 \%, 0.48 \%$, $0.42 \%$, dan $0.41 \%$ yang membuktikan bahwa model yang terbentuk berada pada kriteria peramalan sangat baik sehingga dapat dilakukan peramalan untuk periode selanjutnya. Peramalan menggunakan FTSmarkov chain menghasilkan peramalan selama 24 minggu kedepan.
\end{abstract}

Copyright (C) 2020 Vygotsky: Jurnal Pendidikan Matematika dan Matematika. All right reserved 


\section{PENDAHULUAN}

Indonesia merupakan negara yang menerapkan sistem perekonomian terbuka pada tahun 1969. Dimulai dari tahun tersebut perekonomian di Indonesia dari tahun ke tahun terus mengalami peningkatan. Tingginya angka permintaan dan penawaran dari masyarakat mengharuskan negara untuk melakukan kegiatan ekspor dan impor. Kegiatan tersebut erat kaitannya dengan pergerakan fluktuasi nilai tukar rupiah terhadap mata uang asing (Ardiyanto \& Ma'ruf, 2014). Kestabilan perekonomian suatu negara dapat dilihat dari stabilnya nilai tukar rupiah terhadap mata uang asing. Apabila pertumbuhan ekonomi berjalan dengan stabil maka dapat disimpulkan bahwa suatu negara sedang mengalami kondisi ekonomi yang baik (Triyono, 2008).

Pada tahun 1997-1998 Indonesia pernah mengalami depresiasi nilai tukar setelah diterapkannya kebijakan sistem mengambang bebas pada tanggal 14 Agustus 1997 (Atmadja, 2002). Tahun 1998 nilai tukar rupiah terhadap mata uang asing melemah hingga 70\% dan puncaknya terjadi pada bulan Juli 1998 yaitu nilai tukar rupiah terhadap dollar mencapai angka Rp 14700 per US \$. Selain itu inflasi di Indonesia juga mengalami peningkatan tajam yaitu sebesar $77.6 \%$. Krisis ekonomi di Indonesia mengalami puncaknya ditandai dengan menurunnya pertumbuhan ekonomi yang mencapai angka -13.1\%. Dampak yang dirasakan masyarakat dari krisis ekonomi adalah dari segi sosial, politik, dan budaya (Karmeli \& Fatimah, 2008).

Mata uang asing yang dimaksud dalam penelitian ini adalah mata uang dollar dan yuan. Dollar berperan sebagai mata uang utama dunia. Nilai tukar rupiah terhadap dollar memiliki dampak yang luas bagi kelangsungan perekonomian negara. Besar kecilnya nilai tukar rupiah terhadap mata uang dollar perlu dilakukan pemantauan secara berkala untuk memastikan perekonomian suatu negara dalam keadaan yang stabil ataupun sebaliknya (Bau et al., 2016). Apabila nilai tukar rupiah terhadap dollar terdepresiasi secara terus menerus maka dapat berdampak pada banyaknya hutang negara yang harus dibayar. Oleh karena itu, diperlukan perekonomian yang stabil untuk menghindari hal tersebut. Peramalan nilai tukar rupiah terhadap dollar juga akan berguna bagi para investor, dikarenakan kurs rupiah digunakan oleh para investor sebagai indikator yang mempengaruhi aktivitas dalam pasar global yang berdampak pada untung dan rugi investor dalam melakukan kegiatan investasi (Elvierayani, 2017).

Yuan merupakan mata uang negara China. China merupakan salah satu negara Asia yang cukup berperan pada perdagangan internasional (Ichsan et al., 2016). Negara China juga berperan sebagai raksasa ekonomi dunia pada tahun 2019. Indonesia dan China sudah menjalin kerjasama dalam hal perdagangan dari tahun 1953. Kegiatan perdagangan antara Indonesia dan China dapat mengakibatkan fluktuasi neraca perdagangan yang berdampak juga pada angka nilai tukar rupiah terhadap mata uang yuan. Oleh karenanya, diperlukan peramalan nilai tukar rupiah terhadap mata uang yuan untuk memantau pergerakan perekonomian negara (Jamilah et al., 2016).

Peramalan dapat dilakukan dengan menggunakan metode ilmiah secara 
sistematis dan hasil yang diperoleh diharapkan mendekati dengan keadaan yang sebenarnya (Ningsih, 2016). Metode yang dapat digunakan untuk proses peramalan antara lain adalah ARIMA(Abdulrahman et al., 2018; Ohyver \& Pudjihastuti, 2018), exponential smoothing (Gultom et al., 2015), support vector machine (Putri \& Widodo, 2018) dan beberapa metode yang lainnya. Salah satu alternatif metode peramalan yang dapat digunakan dalam penelitian ini adalah fuzzy time series (FTS) markov chain (Uzun \& Kiral, 2017). Metode tersebut merupakan gabungan dari metode fuzzy time series dengan markov chain. Metode fuzzy time series merupakan suatu metode yang menggunakan konsep logika fuzzy yang diaplikasikan pada data time series, dimana dalam logika fuzzy dapat menjelaskan suatu data yang samar (Nugroho, 2016). Metode FTS-markov chain dapat meminimalisir terjadinya penyimpangan error dan dapat menghasilkan peramalan yang baik. Penelitian peramalan harga penutupan saham menggunakan metode FTS-markov chain menghasilkan prediksi dengan tingkat akurasi yang baik yaitu sebesar $96.52 \%$. Metode FTS-markov chain juga menghasilkan tingkat error dengan menggunakan MAPE yang kecil yaitu sebesar $1.16 \%$ dalam penelitian mengenai prediksi jumlah produksi ayam potong (Puspitasari \& Afianto, 2017; Safitri et al., 2018).

Dari uraian diatas peneliti tertarik melakukan peramalan nilai tukar rupiah terhadap mata uang dollar dan yuan dengan menggunakan metode FTS-markov chain.

\section{METODE PENELITIAN}

Data yang digunakan untuk penelitian ini merupakan data kuantitatif berupa angka nilai tukar rupiah terhadap mata uang dollar dan yuan yang diakses dari https://www.bi.go.id. Data yang digunakan untuk penelitian ini adalah data yang diambil per minggu dimulai pada bulan Januari 2016 sampai dengan bulan Desember tahun 2019. Metode yang digunakan dalam melakukan analisis terhadap data adalah menggunakan metode FTS-markov chain yang merupakan gabungan antara metode fuzzy time series dengan markov chain dengan rancangan penelitian yang digambarkan pada Gambar 1.

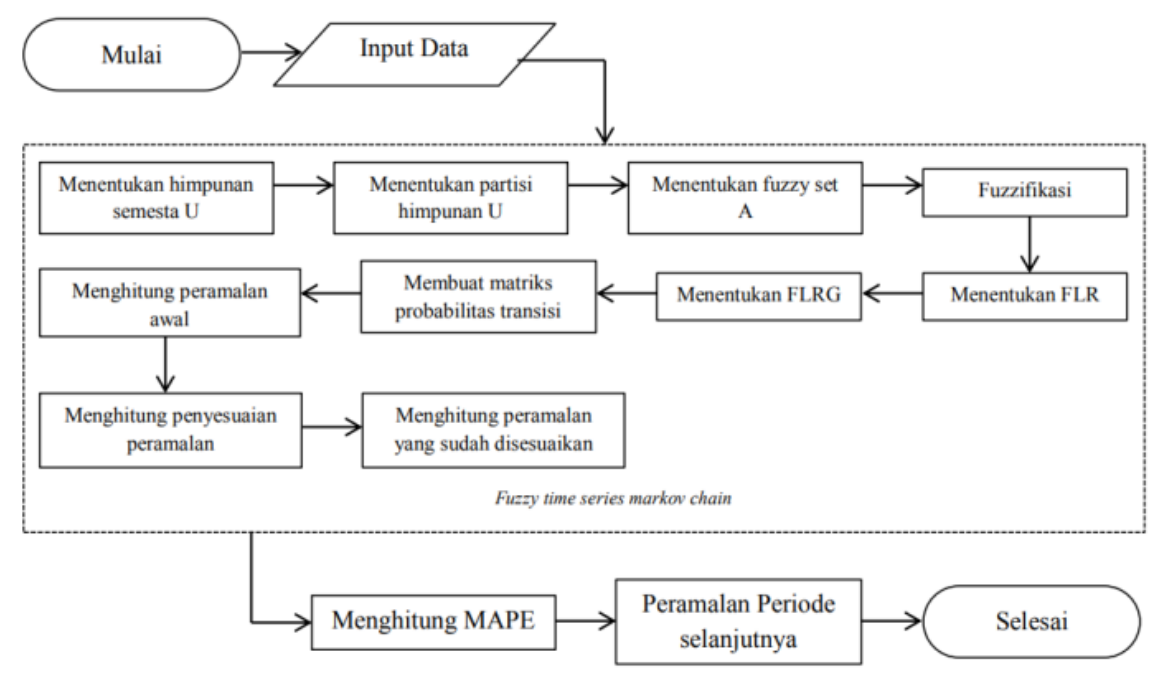


Gambar 1. Diagram alir proses peramalan FTS-markov chain

Dari Gambar 1. dapat dijelaskan rancangan penelitian sebagai berikut.

1. Melakukan input data yang sudah diakses dari https://www.bi.go.id

2. Memproses data yang sudah diinput kedalam metode FTS-markov chain dengan langkah-langkah sebagai berikut (Saputra, 2018; Zhu et al., 2016) :

a. Membentuk himpunan semesta $U$ yang didefinisikan sebagai

$$
\left[D_{\min }-D_{1} ; D_{\max }+D_{2}\right]
$$

b. Menentukan partisi himpunan semesta $U$ menggunakan persamaan sturges $n=1+3.322 \log (N)$

Dengan $N$ merupakan banyaknya data historis. Selanjutnya adalah menentukan panjang interval $(l)$ dengan persamaan

$l=\frac{\left[\left(D_{\max }+D_{2}\right)-\left(D_{\min }-D_{1}\right)\right]}{n}$

Sehingga diperoleh :

$u_{1}=\left[D_{\min }-D_{1} ; D_{\min }-D_{1}+l\right]$

$u_{2}=\left[D_{\text {min }}-D_{1}+l ; D_{\text {min }}-D_{1}+2 l\right]$

$u_{i}=\left[D_{\min }-D_{1}+(n-1) l ; D_{\min }-D_{1}+n l\right]$

Dengan $i=1,2,3, \cdots, n$. $n$ menyatakan banyaknya partisi.

c. Menentukan fuzzy set A yang didefinisikan

$A_{j}=\sum_{i=1}^{n} \frac{\mu_{j}\left(u_{i}\right)}{u_{i}}$

Dimana $\mu_{j}$ merupakan derajat keanggotaan dari himpunan fuzzy $A_{j}$ pada elemen himpunan $u_{i}$, dengan $i=1,2,3, \cdots, n$ dan $0<\mu_{j}<1$. Terdapat syarat-syarat untuk menentukan derajat keanggotaan $\mu_{j}$ yaitu

$\mu_{j}\left(u_{i}\right)=\left\{\begin{array}{cc}1 & ; j=i \\ 0.5 & ; j=i-1 \text { atau } j=i+1 \\ 0 & ; \quad \text { lainnya }\end{array}\right.$

Dari Persamaan (5) himpunan fuzzy $A_{1}, A_{2}, A_{3}, \cdots, A_{j}$ dapat didefinisikan sebagai

$A_{j}=\frac{0}{u_{1}}+\frac{0}{u_{2}}+\frac{0}{u_{3}}+\cdots+\frac{0.5}{u_{i-1}}+\frac{1}{u_{i}}$

d. Fuzzifikasi

Langkah ini bertujuan untuk mengubah variabel numerik menjadi variabel linguistik. Untuk mengubah variabel numerik menjadi variabel linguistik dapat dilakukan dengan cara mengelompokkan data kedalam himpunan A yang sudah didefinisikan sebelumnya.

e. Menentukan Fuzzy Logical Relationship (FLR)

Langkah ini bertujuan untuk mengetahui keterkaitan antar setiap data dengan data selanjutnya dalam bentuk himpunan kabur $A$. FLR dinotasikan sebagai $A_{i} \rightarrow A_{j}$. Dimana $A_{i}$ merupakan current state atau kejadian saat ini dan $A_{j}$ merupakan next state atau kejadian selajutnya.

f. Menentukan Fuzzy Logical Relationship Grup (FLRG)

Langkah ini bertujuan untuk mengelompokan hasil FLR. FLRG dapat dibentuk dengan cara mengelompokkan FLR dengan sisi kiri atau current state yang bersifat tetap. 
g. Membentuk matriks probabilitas transisi berdasarkan nilai FLRG yang sudah didapat. Untuk mendapatkan nilai pada elemen-elemen matriks dapat dilakukan dengan menggunakan Persamaan

$P_{i j}=\frac{M_{i j}}{M_{i}}$

Dengan $i, j=1,2,3, \cdots, n$

Keterangan:

$P_{i j} \quad$ : probabilitas transisi dari kejadian sebelumnya dan selanjutnya

$M_{i j} \quad$ : jumlah transisi dari kejadian sebelumnya dan selanjutnya

$M_{i} \quad$ : jumlah kejadian yang terjadi sebelumnya

h. Defuzzifikasi

1) Peramalan awal

Peramalan awal dapat dihasilkan dengan memperhatikan FLR, FLRG, serta matriks probabilitas transisi yang diperoleh sebelumnya. Peramalan awal $\left(\mathrm{F}_{\mathrm{t}}\right)$ dengan $t=1,2,3, \cdots, N$ dapat dilakukan dengan cara seperti berikut ini.

a) Jika FLRG pada $A_{i}$ adalah kosong $\left(A_{i} \rightarrow \emptyset\right)$ maka hasil peramalan yang didapat adalah nilai tengah $(\mathrm{m})$ dari $u_{i}$ dengan persamaan $F_{t}=m_{i}$

b) Jika FLRG pada $A_{i}$ merupakan relasi satu-satu $\left(A_{i} \rightarrow A_{j}\right)$ maka hasil peramalan yang didapat adalah nilai tengah dari $u_{j}$ dengan persamaan

$F_{t}=m_{j}$

c) Jika FLRG pada $A_{i}$ merupakan relasi satu ke banyak $\left(A_{i} \rightarrow\right.$ $\left.A_{1}, A_{2}, A_{3}, \cdots, A_{j}\right)$ maka hasil peramalan dapat dilakukan dengan menggunakan persamaan sebagai berikut.

$F_{t}=m_{1} P_{i 1}+m_{2} P_{i 2}+\cdots+m_{(i-1)} P_{i(i-1)}+Y_{(t-1)} P_{i}+m_{(i+1)} P_{i(i+1)}+$

$\cdots+m_{n} P_{i j}$

Dengan $Y_{(t-1)}$ merupakan data sebenarnya pada $(t-1)$

2) Penyesuaian peramalan

Adapun aturan yang digunakan pada proses penyesuaian hasil peramalan adalah sebagai berikut :

a) Misalkan terdapat FLR $\left(A_{i} \rightarrow A_{j}\right)$ dan $i<j$ maka nilai penyesuaian hasil peramalan dapat dicari dengan menggunakan persamaan.

$D=\frac{l \times s}{2}$

Dengan $s$ merupakan banyaknya perpindahan transisi maju.

b) Misalkan terdapat FLR $\left(A_{i} \rightarrow A_{j}\right)$ dan $i>j$ maka nilai penyesuaian hasil peramalan dapat dicari dengan menggunakan persamaan.

$D=-\frac{l \times r}{2}$

Dengan $r$ merupakan banyaknya perpindahan transisi mundur.

c) Misalkan terdapat FLR $\left(A_{i} \rightarrow A_{j}\right)$ dan $i=j$ maka nilai penyesuaian hasil peramalan adalah $D=0$.

3) Peramalan akhir 
Peramalan akhir dari proses FTS-markov chain dapat dihitung dengan menggunakan persamaan.

$$
F^{\prime}{ }_{t}=F_{t}+D
$$

3. Hasil peramalan yang didapat kemudian dilakukan evaluasi model FTSmarkov chain menggunakan MAPE dengan persamaan (Kim \& Kim, 2016; Somvanshi \& Kumari, 2020).

$$
M A P E=\frac{\sum_{t=1}^{n}\left|\frac{Y_{t}-F^{\prime} t}{Y_{t}}\right| \times 100 \%}{N}
$$

Keterangan :

$Y_{t}=$ nilai sebenarnya pada waktu ke $t$

$F^{\prime}{ }_{t}=$ nilai peramalan pada waktu ke $t$

$N=$ jumlah data historis

4. Melakukan proses peramalan pada periode selanjutnya jika hasil MAPE memenuhi kriteria yang baik.

\section{HASIL DAN PEMBAHASAN}

Data yang digunakan dari bulan Januari 2016 sampai bulan Desember 2019 berjumlah 209 kemudian dibagi menjadi dua, dengan data pelatihan adalah sebesar $75 \%$ dari total keseluruhan data dan data pengujian adalah sebesar $25 \%$ dari total keseluruhan (Aliek et al., 2018). Oleh karenanya, total data pelatihan adalah sebesar 157 dan data pengujian sebesar 52 data. Model FTS-markov chain data pelatihan dapat dibangun dengan rancangan penelitian yang sudah dijelaskan sebelumnya. Hasil peramalan pada data pelatihan disajikan pada Tabel 1 dan Tabel 2.

Tabel 1. Hasil Peramalan Data Pelatihan Nilai Tukar Rupiah Terhadap Dollar

\begin{tabular}{cccccc}
\hline & & \multicolumn{2}{c}{ Kurs Jual Dollar } & \multicolumn{2}{c}{ Kurs Beli Dollar } \\
\cline { 3 - 6 } No & Tanggal & $\begin{array}{c}\text { Data } \\
\text { aktual }\end{array}$ & $\begin{array}{c}\text { Hasil } \\
\text { peramalan }\end{array}$ & $\begin{array}{c}\text { Data } \\
\text { aktual }\end{array}$ & $\begin{array}{c}\text { Hasil } \\
\text { peramalan }\end{array}$ \\
\hline 1. & $4-1-^{\prime} 16$ & 13967 & - & 13829 & - \\
2. & $11-1-^{\prime} 16$ & 14005 & 14005.1 & 13865 & 13866.7 \\
3. & $18-1-^{\prime} 16$ & 14001 & 14034.3 & 13861 & 13894.4 \\
4. & $25-1-^{\prime} 16$ & 13913 & 14031.3 & 13775 & 13891.3 \\
5. & $1-2-^{\prime} 16$ & 13767 & 13819.8 & 13631 & 13682.7 \\
$\vdots$ & $\vdots$ & $\vdots$ & $\vdots$ & $\vdots$ & $\vdots$ \\
153. & $3-12-{ }^{\prime} 18$ & 14323 & 14478.1 & 14181 & 14333.6 \\
154. & $10-12-18$ & 14590 & 14539.2 & 14444 & 14381.4 \\
155. & $17-12-18$ & 14690 & 14593.5 & 14544 & 14448.3 \\
156. & $24-12-18$ & 14675 & 14676.9 & 14529 & 14530.1 \\
157. & $31-12-' 18$ & 14553 & 14664.4 & 14409 & 14517.8 \\
\hline
\end{tabular}

\begin{tabular}{|c|c|c|c|c|c|}
\hline \multirow{2}{*}{ No } & \multirow{2}{*}{ Tanggal } & \multicolumn{2}{|c|}{ Kurs Jual Yuan } & \multicolumn{2}{|c|}{ Kurs Beli Yuan } \\
\hline & & Data & Hasil & Data & Hasil \\
\hline
\end{tabular}

Tabel 2. Hasil Peramalan Data Pelatihan Nilai Tukar Rupiah Terhadap Yuan 


\begin{tabular}{cccccc} 
& & \multicolumn{3}{c}{ aktual } & peramalan \\
\cline { 3 - 6 } 1. & $4-1-^{\prime} 16$ & 2147.71 & - & 2126.49 & - \\
2. & $11-1-^{\prime} 16$ & 2134.06 & 2147.2 & 2112.73 & 2123.3 \\
3. & $18-1-^{\prime} 16$ & 2134.62 & 2137.8 & 2113.28 & 2114.7 \\
4. & $25-1-^{\prime} 16$ & 2122.28 & 2138.2 & 2101.22 & 2115.0 \\
\hline & & \multicolumn{2}{c}{ Kurs Jual Yuan } & \multicolumn{2}{c}{ Kurs Beli Yuan } \\
\cline { 3 - 6 } No & Tanggal & Data & Hasil & Data & Hasil \\
& & aktual & peramalan & aktual & peramalan \\
\hline 5. & $1-2-^{\prime} 16$ & 2100.58 & 2111.2 & 2079.83 & 2089.3 \\
$\vdots$ & $\vdots$ & $\vdots$ & $\vdots$ & $\vdots$ & $\vdots$ \\
153. & $3-12-^{\prime} 18$ & 2062.91 & 2073.1 & 2042.46 & 2052.5 \\
154. & $10-12-' 18$ & 2123.94 & 2104.0 & 2102.69 & 2081.4 \\
155. & $17-12-' 18$ & 2131.83 & 2130.9 & 2110.64 & 2108.4 \\
156. & $24-12-{ }^{\prime} 18$ & 2131.60 & 2136.3 & 2110.39 & 2133.4 \\
157. & $31-12-18$ & 2120.44 & 2136.1 & 2099.46 & 2094.9 \\
\hline
\end{tabular}

Pengujian model fuzzy time series markov chain dilakukan pada data nilai tukar rupiah terhadap mata uang dollar dan mata uang yuan sebesar 25\% dari total data. Peramalan pada data testing dilakukan dengan menggunakan model yang sudah diperoleh dari data pelatihan. Hasil peramalan data pengujian disajikan pada Tabel 3 dan Tabel 4.

Tabel 3. Hasil Peramalan Data Pengujian Nilai Tukar Rupiah Terhadap Dollar

\begin{tabular}{cccccc}
\hline & & \multicolumn{2}{c}{ Kurs Jual Dollar } & \multicolumn{2}{c}{ Kurs Beli Dollar } \\
\cline { 3 - 6 } No & Tanggal & $\begin{array}{c}\text { Data } \\
\text { aktual }\end{array}$ & $\begin{array}{c}\text { Hasil } \\
\text { peramalan }\end{array}$ & $\begin{array}{c}\text { Data } \\
\text { aktual }\end{array}$ & $\begin{array}{c}\text { Hasil } \\
\text { peramalan }\end{array}$ \\
\hline 158. & $7-1-^{\prime} 19$ & 14176 & - & 14034 & - \\
159. & $14-1-^{\prime} 19$ & 14122 & 14165.9 & 13982 & 14024.4 \\
160. & $21-1-^{\prime} 19$ & 14283 & 14268.1 & 14141 & 14126.9 \\
161. & $28-1-^{\prime} 19$ & 14108 & 14241.7 & 13968 & 14080.4 \\
162. & $4-2-^{-1} 19$ & 14046 & 14113.6 & 13906 & 13973.6 \\
$\vdots$ & $\vdots$ & $\vdots$ & $\vdots$ & $\vdots$ & $\vdots$ \\
205. & $2-12-{ }^{\prime} 19$ & 14192.6 & 14298.4 & 14051.4 & 14156.6 \\
206. & $9-12-19$ & 14091.1 & 14219.1 & 13950.9 & 14044.5 \\
207. & $16-12-' 19$ & 14074.0 & 14100.6 & 13933.1 & 13960.5 \\
208. & $23-12-^{\prime} 19$ & 14047.9 & 14087.4 & 13908.1 & 13947.5 \\
209. & $30-12-^{\prime} 19$ & 14014.7 & 14067.3 & 13875.3 & 14517.8 \\
\hline
\end{tabular}

Tabel 4. Hasil Peramalan Data Pengujian Nilai Tukar Rupiah Terhadap Yuan

\begin{tabular}{lccccc}
\hline \multirow{2}{*}{ No } & Tanggal & \multicolumn{2}{c}{ Kurs Jual Yuan } & \multicolumn{2}{c}{ Kurs Beli Yuan } \\
\cline { 3 - 6 } & & aktual & $\begin{array}{c}\text { Hasil } \\
\text { peramalan }\end{array}$ & $\begin{array}{c}\text { Data } \\
\text { aktual }\end{array}$ & $\begin{array}{c}\text { Hasil } \\
\text { peramalan }\end{array}$ \\
\hline 158. & $7-1-^{\prime} 19$ & 2068.98 & - & 2048.25 & - \\
159. & $14-1-^{\prime} 19$ & 2090.29 & 2123.9 & 2069.57 & 2066.94 \\
160. & $21-1-^{\prime} 19$ & 2107.45 & 2084.8 & 2086.49 & 2064.03 \\
161. & $28-1-^{-19}$ & 2090.94 & 2093.4 & 2070.19 & 2071.55
\end{tabular}




$\begin{array}{cccccc}\vdots & \vdots & \vdots & \vdots & \vdots & \vdots \\ 205 . & 2-12-{ }^{\prime} 19 & 2019.09 & 2020.2 & 1998.89 & 2002.96 \\ 206 . & 9-12-19 & 2004.08 & 2006.2 & 1983.30 & 1982.42 \\ 207 . & 16-12-^{\prime} 19 & 2012.73 & 2015.0 & 1991.85 & 1997.15 \\ 208 . & 23-12-^{\prime} 19 & 2003.52 & 2001.2 & 1983.50 & 1984.34 \\ 209 . & 30-12-^{\prime} 19 & 2005.46 & 1996.1 & 1985.36 & 1979.08\end{array}$

Adapun plot dari data aktual dan hasil peramalan nilai tukar rupiah terhadap dollar dan yuan pada Gambar 2.

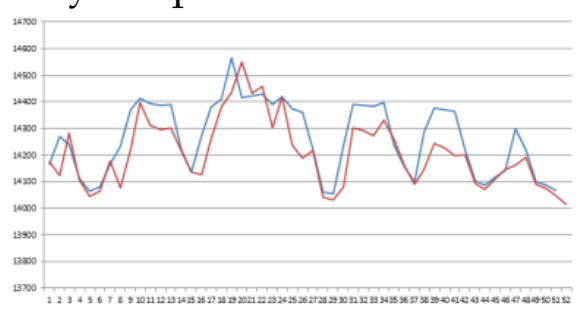

(a)



(c)

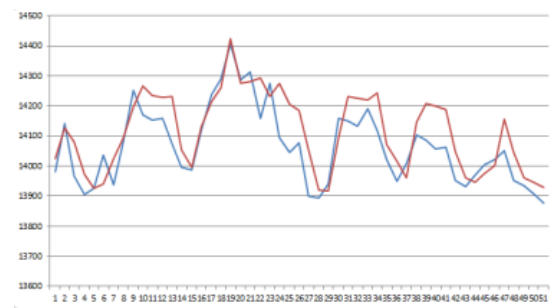

(b)

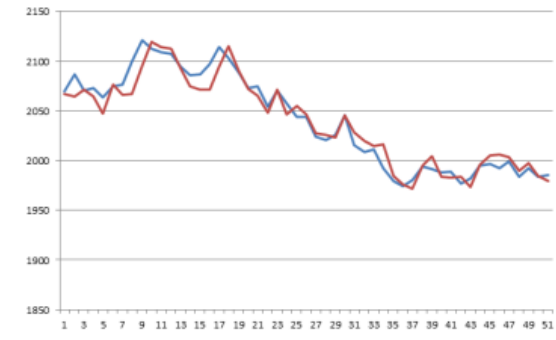

(d)

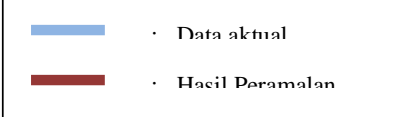

Gambar 2. Plot Data Aktual dan Hasil Peramalan (a) nilai tukar jual dollar, (b) nilai tukar beli dollar, (c) nilai tukar jual yuan, (d) nilai tukar beli yuan

Pada Gambar 2 menunjukkan bahwa hasil peramalan mengikuti pola dari data aktual, maka disimpulkan bahwa peramalan dengan menggunakan FTS-markov chain memiliki hasil yang mendekati data aktual.

Untuk mengetahui apakah suatu model yang sudah dibuat pada data pelatihan layak digunakan atau tidak maka perlu dilakukan pengujian pada data testing dengan cara menghitung nilai error pada data pengujian yang sudah dilakukan peramalan. Perhitungan error dapat dilakukan dengan menggunakan Persamaan (14). Hasil error (MAPE) pada masing-masing data disajikan pada Tabel 5.

Tabel 5. MAPE masing-masing data

\begin{tabular}{cc}
\hline Data & $\begin{array}{c}\text { Nilai MAPE } \\
(\%)\end{array}$ \\
\hline Kurs Jual Dollar & 0.53 \\
Kurs Beli Dollar & 0.48 \\
Kurs Jual Yuan & 0.42 \\
Kurs Beli Yuan & 0.41 \\
\hline
\end{tabular}

Hasil MAPE menunjukkan bahwa model yang dibentuk pada data pelatihan 
memenuhi kriteria MAPE sangat baik karena masing-masing data memiliki nilai error kurang dari $10 \%$. Hasil dari error yang didapat sesuai dengan penelitianpenelitian yang sudah dilakukan sebelumnya yang menyatakan bahwa metode FTS-markov chain dapat meminimalisir error dan dapat menghasilkan peramalan yang baik (Ningsih, 2016). Dari hasil error tersebut maka model yang dibangun oleh FTS-markov chain untuk data nilai tukar rupiah terhadap dollar dan yuan dapat digunakan untuk peramalan pada bulan Januari sampai Juni 2020. Hasil peramalan kurs rupiah terhadap dollar dan yuan disajikan pada Tabel 6.

Tabel 6. Hasil Peramalan FTS-MC 24 Minggu Kedepan

\begin{tabular}{ccccc}
\hline \multirow{2}{*}{$\mathrm{t}$} & \multicolumn{2}{c}{ Dollar } & \multicolumn{2}{c}{ Yuan } \\
\cline { 2 - 5 } & Kurs Jual & Kurs Beli & Kurs Jual & Kurs Beli \\
\hline 210 & 14041.81 & 13902.33 & 1997.57 & 1980.59 \\
211 & 14082.26 & 13942.56 & 1990.41 & 1973.15 \\
212 & 14062.64 & 13923.14 & 1991.54 & 1974.30 \\
213 & 14093.76 & 13954.09 & 1986.07 & 1968.61 \\
214 & 14078.67 & 13939.15 & 1986.94 & 1969.49 \\
215 & 14102.60 & 13962.95 & 1982.75 & 1965.14 \\
216 & 14090.99 & 13951.46 & 1983.41 & 1965.82 \\
217 & 14109.41 & 13969.77 & 1980.21 & 1962.49 \\
218 & 14100.48 & 13960.93 & 1980.71 & 1963.00 \\
219 & 14114.64 & 13975.02 & 1978.26 & 1960.46 \\
220 & 14107.77 & 13968.21 & 1978.65 & 1960.85 \\
221 & 14118.67 & 13979.05 & 1976.78 & 1958.91 \\
222 & 14113.38 & 13973.82 & 1977.07 & 1959.21 \\
223 & 14121.76 & 13982.15 & 1975.64 & 1957.72 \\
224 & 14117.70 & 13978.13 & 1975.87 & 1957.95 \\
225 & 14124.14 & 13984.54 & 1974.77 & 1956.81 \\
226 & 14121.02 & 13981.45 & 1974.95 & 1956.99 \\
227 & 14125.98 & 13986.38 & 1974.11 & 1956.12 \\
228 & 14123.57 & 13983.10 & 1974.24 & 1956.25 \\
229 & 14127.38 & 13987.79 & 1973.60 & 1955.59 \\
230 & 14125.54 & 13985.96 & 1973.70 & 1955.69 \\
231 & 14128.47 & 13988.88 & 1973.21 & 1955.18 \\
232 & 14127.05 & 13987.47 & 1973.29 & 1955.26 \\
233 & 14129.30 & 13989.71 & 1972.92 & 1954.87 \\
\hline & & & &
\end{tabular}

Berdasarkan Tabel 6 pada data nilai tukar rupiah terhadap dollar dan yuan menghasilkan peramalan selama 6 bulan kedepan, mulai dari tanggal 6 Januari 2020 sampai dengan tanggal 15 Juni 2020. Metode FTS-markov chain pada hakikatnya sangat bagus untuk peramalan satu periode kedepan, oleh karenanya untuk menghasilkan peramalan pada saat $\mathrm{t}=211$ sampai dengan $\mathrm{t}=$ 233 dapat memanfaatkan nilai output peramalan untuk dijadikan sebagai variabel input. Akan tetapi, pada metode FTS-markov chain memiliki kelemahan yaitu semakin panjang periode peramalan akan semakin besar pula tingkat error yang diberikan. Oleh karenanya, pada penelitian ini periode peramalan dibatasi 
sampai 24 periode peramalan saja.

Hasil peramalan nilai tukar rupiah terhadap dollar menunjukan dari minggu ke minggu mengalami peningkatan hingga mencapai angka Rp14129.30 dan Rp13989.31 pada kurs jual dan beli dollar, hal tersebut menunjukkan bahwa nilai tukar rupiah terhadap dollar diprediksikan mengalami depresiasi dalam beberapa waktu kedepan. Sedangkan hasil peramalan nilai tukar rupiah terhadap yuan menunjukan pergerakan dari minggu ke minggu yang semakin menurun hingga mencapai angka kurs jual dan beli sebesar Rp1972.92 dan Rp1954.87 atau dapat disimpulkan bahwa nilai tukar rupiah terhadap yuan diprediksi akan mengalami apresiasi atau menguat.

\section{SIMPULAN}

Dari uraian yang telah dijelaskan pada maka dapat disimpulkan bahwa nilai MAPE untuk data nilai tukar jual dollar, nilai tukar beli dollar, nilai tukar jual yuan, dan nilai tukar beli yuan masing-masing adalah $0.53 \%, 0.48 \%, 0.42 \%$ dan $0.41 \%$ yang menunjukkan model FTS-markov chain pada data nilai tukar rupiah terhadap dollar dan yuan berada pada kriteria peramalan sangat baik.

Peramalan nilai tukar rupiah terhadap dollar dan mata uang yuan mendapatkan 24 peramalan periode selanjutnya pada masing-masing data yaitu pada tanggal 6 Januari 2020 sampai 15 Juni 2020. Hasil peramalan nilai tukar rupiah terhadap dollar dari minggu ke minggu mengalami peningkatan, hal tersebut menunjukkan bahwa nilai tukar rupiah terhadap dollar diprediksikan mengalami depresiasi dalam beberapa waktu kedepan. Sedangkan hasil peramalan nilai tukar rupiah terhadap yuan menunjukan pergerakan dari minggu ke minggu yang semakin menurun atau dapat disimpulkan bahwa nilai tukar rupiah terhadap yuan diprediksi akan mengalami apresiasi atau menguat.

\section{SARAN}

Untuk penelitian selanjutnya, peramalan nilai tukar rupiah terhadap mata uang dollar dan mata uang yuan dapat dilakukan dengan metode peramalan yang lain seperti, metode support vector machine (SVM) atau dengan menggunakan metode yang lain sehingga dapat menghasilkan peramalan yang lebih baik dan dapat dijadikan sebagai pembanding antara menggunakan metode FTS-markov chain dengan metode yang lain. Selain itu, perlu juga dilakukan pada data nilai tukar rupiah terhadap mata uang asing lainnya. Sehingga memperkaya informasi posisi kurs rupiah terhadap mata uang asing.

\section{DAFTAR PUSTAKA}

Abdulrahman, B. M. A., Ahmed, A. Y. A., \& Abdellah, A. E. Y. (2018). Forecasting of Sudan Inflation Rates using ARIMA Model. International Journal of Economics and Financial Issues, 8(3), 17-22.

Aliek, B. R. D. P., Hafiyusholeh, M., Ulinnuha, N., \& Setiawan, F. (2018). Penerapan Model FTS-Markov Chainuntuk Peramalan Cuaca di Jalur Penyeberangan Gresik-Bawean. Prosiding Seminar Nasional Integrasi 
Matematika Dan Nilai Islami, 2(1), 1-9.

Ardiyanto, F., \& Ma'ruf, A. (2014). Pergerakan Nilai Tukar Rupiah Terhadap Dolar Amerika Dalam Dua Periode Penerapan Sistem Nilai Tukar. Jurnal Ekonomi Dan Studi Pembangunan, 15(2), 127-134.

Atmadja, A. S. (2002). Analisa Pergerakan Nilai Tukar Rupiah Terhadap Dolar Amerika Setelah Diterapkannya Kebijakan Sistem Nilai Tukar Mengambang Bebas Di Indonesia. Jurnal Akuntansi Dan Keuangan, 4(1), 69-78.

Bau, A. F., Kumaat, J. R., \& Niode, O. A. (2016). Faktor-Faktor Yang Mempengaruhi Fluktuasi Nilai Tukar Rupiah Terhadap Dolar Amerika Serikat. Jurnal Berkala Ilmiah Efisiensi, 16(3), 524-535.

Elvierayani, R. R. (2017). Peramalan Nilai Tukar (Kurs) Rupiah Terhadap Dolar Tahun 2017 dengan Menggunakan Metode Arima Box-Jenkins. Prosiding SI MaNIs, 1(1), 253-261.

Gultom, N. Y., Sudarno, \& Wuryandari, T. (2015). Prediksi Nilai Kurs Dollar Amerika Menggunakan Exponential Smoothing Dengan Kajian Grafik Moving Average (MA) dan Exponentially Weighted Moving Average (EWMA) (Studi Kasus: Kurs Jual dan Kurs Beli Dollar Amerika). Jurnal Gaussian, 4(4), 957-966.

Ichsan, S., Suhadak, \& Sulasmiyati, S. (2016). Pengaruh Pergerakan Nilai Tukar Yuan Terhadap Ekspor Dan Impor Indonesia (Studi Pada Bank Indonesia Periode 2012-2014). Jurnal Administrasi Bisnis, 35(2), 94-103.

Jamilah, Sinaga, B. M., Tambunan, M., \& Hakim, D. B. (2016). Dampak Perlambatan Ekonomi China Dan Devaluasi Yuan Terhadap Kinerja Perdagangan Pertanian Indonesia. Jurnal Ekonomi Dan Keuangan, 25(3), 325345.

Karmeli, E., \& Fatimah, S. (2008). Krisis Ekonomi Indonesia. Journal of Indonesian Applied Economics, 2(2), 164-173.

Kim, S., \& Kim, H. (2016). A New Metric Of Absolute Percentage Error For Intermittent Demand Forecasts. International Journal of Forecasting, 32(3), 669679.

Ningsih, F. K. (2016). Peramalan Kurs Rupiah Terhadap Dolar Dengan Metode Berbasis Rata-Rata Fuzzy Time Series Markov Chain. Institut Pertanian Bogor.

Nugroho, K. (2016). Model Analisis Prediksi Menggunakan Metode Fuzzy Time Series. Jurnal INFOKAM, 12(1), 46-50.

Ohyver, M., \& Pudjihastuti, H. (2018). Arima Model for Forecasting the Price of Medium Quality Rice to Arima Model for Forecasting the Price of Medium Quality Rice to Anticipate Price Fluctuations Anticipate Price Fluctuations. Procedia Computer Science, 135, 707-711. https://doi.org/10.1016/j.procs.2018.08.215

Puspitasari, D. I., \& Afianto, M. A. (2017). Implementasi Fuzzy Time Series Markov Chain Model (Ftsmcm) Dalam Prediksi Jumlah Produksi Ayam Potong. JTIULM, 2(2), 14-20.

Putri, R. M., \& Widodo, E. (2018). Application Of Support Vector Machine Method For Rupiah Exchange Rate To Us Dollar Forecasting. Seminala Nasional Edusaintek., 27-36. 
Safitri, Y., Wahyuningsih, S., \& Goejantoro, R. (2018). Peramalan Dengan Metode Fuzzy Time Series Markov Chain (Studi Kasus : Harga Penutupan Saham PT. Radiant Utama Interinsco Tbk Periode Januari 2011 -Maret 2017). Jurnal EKSPONENSIAL, 9(1), 51-58.

Saputra, B. D. (2018). A Fuzzy Time Series-Markov Chain Model To Forecast Fish Farming Product. Jurnal Ilmiah Kursor, 9(4), 129-138.

Somvanshi, S. S., \& Kumari, M. (2020). Applied Computing And Geosciences Comparative Analysis Of Different Vegetation Indices With Respect To Atmospheric Particulate Pollution Using Sentinel Data. Applied Computing and Geosciences, 7. https://doi.org/10.1016/j.acags.2020.100032

Triyono. (2008). Analisis Perubahan Kurs Rupiah Terhadap Dollar Amerika. Jurnal Ekonomi Pembangunan, 9(2), 156-167.

Uzun, B., \& Kiral, E. (2017). Application Of Markov Chains-Fuzzy States To Gold Price. Procedia Computer Science, 120, 365-371.

Zhu, D.-M., Ching, W.-K., \& Guu, S.-M. (2016). Sufficient Conditions For The Ergodicity Of Fuzzy Markov Chains. Fuzzy Sets and System, 304, 82-93. https://doi.org/10.1016/j.fss.2016.01.005 